\title{
SCHEMATIC REPRESENTATION: HOW STUDENTS CREATING IT?
}

\author{
Rahmad Bustanul Anwar $^{1}$, Dwi Rahmawati ${ }^{2}$, \& Kristina Widjajanti ${ }^{3}$ \\ ${ }^{1,2}$ Universitas Muhammadiyah Metro, ${ }^{3}$ Politeknik Negeri Malang \\ rarachmadia@gmail.com
}

\begin{abstract}
Abstrak
Penelitian ini bertujuan untuk mendeskripsikan proses terbentuknya representasi skematis murni dan representasi skematis campuran yang diciptakan oleh siswa selama menyelesaikan word problem. Jenis penelitian yang digunakan adalah kualitatif yang bersifat deskriprif. Dalam penelitian ini melibatkan 45 siswa kelas 8 . Sedangkan untuk memilih subjek tidak dipilih secara acak, namun dipilih berdasarkan kemampuan siswa dalam menciptkan representasi skematik. Pengumpulan data dilakukan dengan meminta siswa untuk menyelesaikan Tugas Pemecahan Masalah secara think aload, yaitu siswa diminta untuk menyuarakan apa yang dipikirkannya. Selain itu siswa juga menuangkan pikirannya mengunakan kertas dan pensil. Hasil penelitian ini menunjukkan bahwa proses representasi skematis murni diciptakan siswa dengan membuat gambar skema berupa garis besar dari masalah dan dilengkapi dengan beberapa keterangan pokok yang ada dalam masalah. Sedangkan proses representasi skematis campuran diciptakan siswa dengan membuat gambar skema yang dilengkapi dengan keterangan-keterangan dan gambar nyata yang sesuai dengan situasi dalam masalah. Kedua jenis representasi skematis ini sangat efektif dalam membantu siswa dalam menyelesaikan word problem.
\end{abstract}

Kata kunci: representasi skematis, representasi skematis murni, representasi skematis campuran.

\begin{abstract}
This study aims to describe the process of formation of pure schematic representation and mixed schematic representation created by students during solving word problem. The type of research used is descriptive qualitative. In this study involving 45 students $8^{\text {th }}$ grade. While to select the subject not selected at random, but selected based on the ability of students in creating schematic representation. The data collection is done by asking the students to solve the Problem-solving Tasks of think a load, ie the students are asked to voice what they think. In addition students also pour their minds using paper and pencil. The results of this study indicate that the process of pure schematic representation is created by creating schematic drawings in the form of an outline of the problem and supplemented with some basic information that exists in the problem. While the process of mixed schematic representation was created by the students by drawing schematic drawings with explanations and real images that fit the situation in the problem. Both types of schematic representation is very effective in assisting students in solving word problem.
\end{abstract}

Keywords: representation, schematic representation, pure schematic, mixed schematic.

Sitasi: Anwar, B.R. Rahmawati, D. Widjajanti, K. 2019. Schematic Representation: How Students Creating It?. Matematika dan Pembelajaran, 7(1), 1-21. 


\section{INTRODUCTION}

Mathematical problem solving in the form of word problem has received much attention (Hegarty \& Kozhevnikov, 1999; Pape, 2003; Boonen, at al. 2013; Jupri \& Drijvers, 2016; Vula, at al. 2017). One of the student difficulties in solving the problem is the difficulty of students to produce a visual representation which is appropriate to the problem situation (Hegarty \& Kozhevnikov, 1999). One type of mathematical representations that can assist students in solving word problem is schematic representation (Hegarty \& Kozhenikov, 1999; Fagnant \& Vlassis, 2013; Boonen, et al., 2014; Anwar, et al., 2017). Boonen, et al. (2014) state that a visual representation is expressed as an accurate schematic representation if students can draw pictures or diagrams, use gestures, or present a specific mental image that contains the corresponding relationship between the relevant solution elements in the problem.

The use of a schematic representation strongly supports the students in solving word problems (Boonen et al., 2014) because with a schematic representation the students are able to issue of main data on the problem and know the relationships of the information contained in the problem (Hegarty \& Kozhenikov, 1999). In addition with the schematic representation students can illustrate a clear and appropriate relationship and the situation in the problem (Zahner \& Corter, 2010). So by using the scheme, students can have a cognitive structure that contains an organized planning for an activity and guide it in action (VandenBos , 2015).

The students' ability to make schematic representations varies widely. Fagnant \& Vlassis (2013) find two types of schematic representations namely schematic diagrams and drawings used by fourth graders in solving arithmetic problems. Boonen, et al. (2014) in their research find two types of schematic representation namely accurate schematic representation and inaccurate schematic representation used by sixth grade students in solving word problems. While Muttaqien (2016) finds a kind of schematic representation and a picto-schematic representation resulted by students in solving word problems. Of the several studies 
that have been done have not found the type of pure schematic representation and mixed schematic representation.

Researches related to the use of a schematic representation in solving mathematical problems have been carried out, including: Hegarty \& Kozhenikov, 1999; Fagnant \& Vlassis, 2013; Boonen, et al., 2014; Muttaqien, 2016; and Faruq, et al., 2016. However, based on the results of research that has been done, has not emerged a study that specifically describes the process of formation of pure schematic representation and mixed schematic representation. Therefore, the focus of this research is to see how the pure schematic representation and mixed representation are produced by the students for completing word problems.

To explore the process of formation of pure schematic representation and mixed schematic representation in solving the problem, this study refers to the problem-solving stage developed by Polya. This is because the stages of problem solving can be used to trace the process of formation of schematic representation. Polya problem solving steps (1973) include four things, namely: 1) Understanding the problem, 2) Devising a plan, 3) Carrying out the plan, and 4) Looking back.

\section{METHOD}

This type of research is descriptive qualitative research, which aims to describe the process of pure schematic representation and mixed schematic representation. This research was conducted at State Junior High School 4 Metro with involving 45 students. The selection of research subjects is done by giving the student problem solving sheet. Each student completes the task by think aload ie students are asked to voice what is thought and put it in a paper. The process of completing the task is recorded using a video recorder. Based on student work, the researcher classifies based on the schematic representation that students use in completing the task. Then the researchers chose two students for each classification. From the selection results obtained four subjects are divided into two groups. The first group consists of S1 and S2 for subjects who use pure schematic representation in problem solving. While group 2 consists of S3 and S4 where the subjects use a mixed schematic representation in problem solving. 
The instrument in this research is the researcher himself equipped with the problem solving sheet. Before the problem solving work sheet is used, the researcher performs expert validation. In the process of completing the task, the student is asked to express clearly what he or she is holding. During this process, researchers observe and record everything done by students. If there is something that is not yet known by the researchers, the researchers conducted interviews to dig up information that has not been known by researchers. The problem-solving tasks used in this study were: "An adventurer establishes a travel route that will run as far as 60 kilometers. He starts his journey on foot as far as 5 kilometers. Then a truck driver gives him a ride. When the truck driver drops him off, he still has half of his journey. How far has he traveled using a truck? ".

\section{RESULT AND DISCUSSION}

The following is presented a description of pure schematic representation process and mixed schematic representation process as follows:

\section{A. Description of Pure Schematic Representation Process}

\section{Subject 1 (S1)}

\section{Understanding the Problem Stage}

The stage of understanding the problem began with reading the Problem Solving Task (TPM). After the subject understood the content of the problem, the subject wrote the known information of the problem. In writing down the known information, the subject used sentences that he understood from the problem. In addition to writing down the information that was known, the subject also wrote questions from the problem. This corresponds to the following Figure 1:

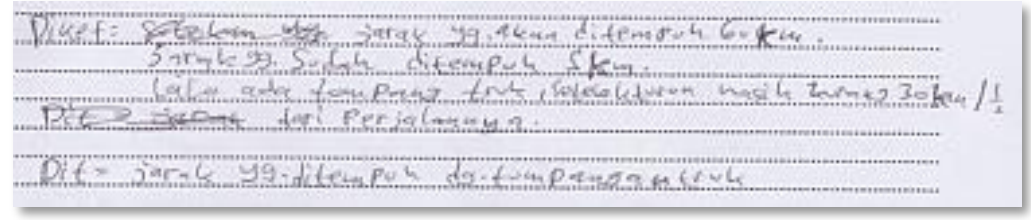

Figure 1. The subject writes the known information from the problem 
Description of Figure 1:

It is known:

- The distance to be reached is 60 kilometers

- Distance traveled is 5 kilometers

- $\quad$ Then there is a truck, having dropped still need 30

kilometers or $1 / 2$ of the way.

Asked: Distance traveled by truck?

\section{Devising a Plan Stage}

At devising a plan stage, the subject created a schematic drawing by creating a line.

The line represented the trip distance to be traveled by an adventurer as far as 60 kilometers. Next, the subject gave a mark below the line by using the arrow. The first arrow was captioned "5 kilometers walk," the second arrow was captioned "lift truck", then the third arrow was captioned "30 kilometers". At preparing plan stage, the subject succeeded in determining the strategy to solve the problem. It is as illustrated as follows (Fig. 2):

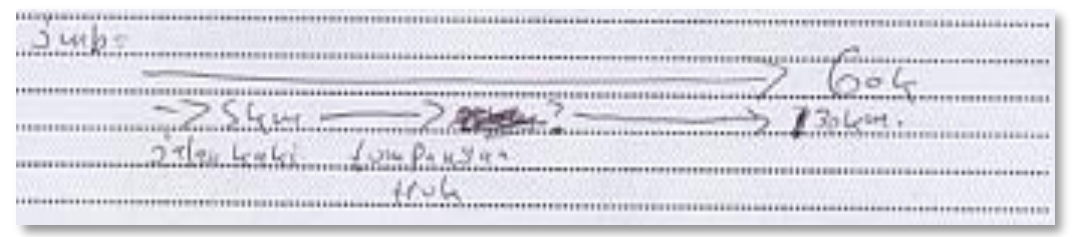

Figure 2. The scheme created by the subject to devising a plan

\section{Carrying Out the Plan Stage}

At carrying out the plan stage, the subject did calculation based on the strategy that he composed in preparing the plan stage. Subject did calculation as follows: $60-$ $30-5=25$ kilometers. In calculating, the subject subtracted the length of the travel route minus half the journey minus traveled by foot. So it was obtained the distance traveled by truck. By using the scheme created in preparing the plan, the subject succeeded in doing the calculation. This is in accordance with the activity that the subject performed in the calculations shown in the following Figure 3: 


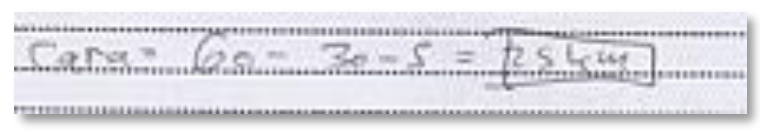

Figure 3. Counting activity

\section{Looking Back Stage}

At looking back stage, the activities undertaken by the subject were reading and looking at the result of his work. Then the subject wrote a sentence that stated the conclusion of the problem-solving process that he did. The conclusion that the subject wrote was "so the distance traveled by truck is 25 kilometers". This corresponds to the following Figure 4:

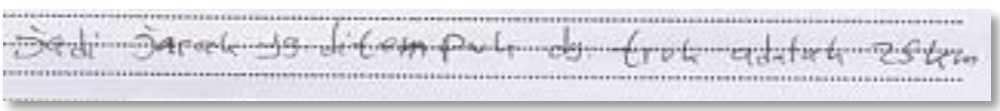

Figure 4. The subject writes the conclusion to answer the problem question Description of Figure 4:

Thus, the distance traveled by truck is 25 kilometers

The pure schematic representation process structure by $\mathrm{S} 1$ is globally presented in the following Figure 5:

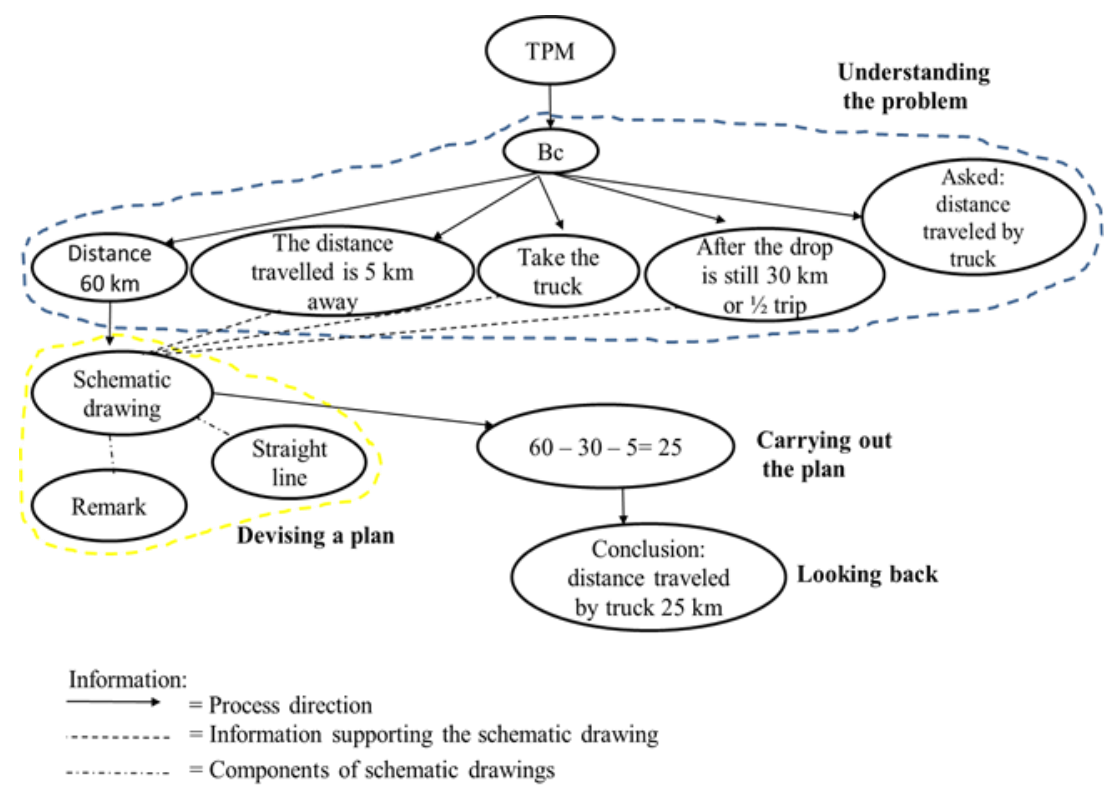

Description of Figure 5 in Table 1: 
Table 1. Term of Pure Schematic Representation Code of S1

\begin{tabular}{ll}
\hline \multicolumn{1}{c}{ Term } & \multicolumn{1}{c}{ Code } \\
\hline Problem solving task & Bc \\
\hline Reading problem activity & \\
\hline Distance of travel route to be run is 60 & Distance $60 \mathrm{~km}$ \\
kilometers & Take the truck \\
\hline The distance that has been taken by the & The distance travelled is 5 \\
adventurer is 5 kilometers walk & kilometers away \\
\hline Adventurer gets a ride on a truck & After the drop is still 30 km or \\
\hline After getting off the truck, the adventurer still \\
has half of his route & Asked: distance traveled by \\
\hline The question of the problem is "how much is & truck \\
distance of the truck taken" & Schematic drawing \\
\hline The subject makes a schematic drawing & Remark \\
\hline The information in the problem & Straight line \\
\hline Schematic drawing is a straight line & $60-30-5=25$ \\
\hline Counting activity & bonclusion: distance traveled \\
\hline Looking back activity & km \\
\hline
\end{tabular}

\section{Subject 2 (S2)}

\section{Understanding the Problem Stage}

In understanding the problem stage, the subject started by reading the given TPM. After reading the TPM, the subject tried to understand the content of the problem. The Activity undertaken while understanding the matter, the subject wrote all the information that was in the problem. In writing down the known information of the problem, the subject wrote the known information exactly the same as the information contained in the problem. This corresponds to the following Figure 6: 


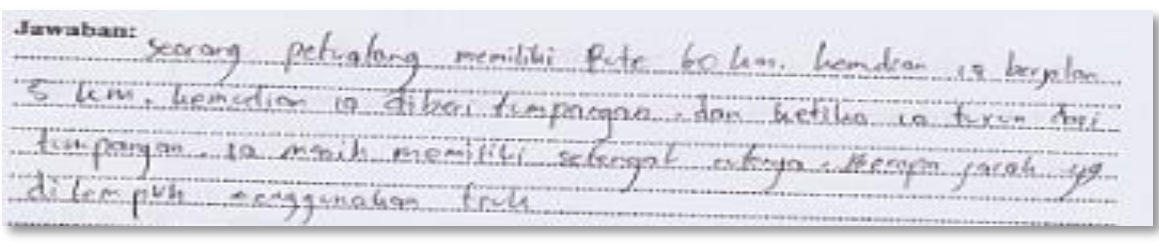

Figure 6. The subject writes the known information from the problem

\section{Description of Figure 6:}

An adventurer has a 60 kilometers route. Then he walks for 5 kilometers. Then he is given a ride and when he gets off the ride, he still has half the route. How far does he travel by truck.

\section{Devising a Plan Stage}

At devising a plan stage, the subject began by identifying the information known from the problem. Then the subject created a schematic drawing using a line equipped with some descriptions. The information used in making the scheme included numbers "0, 5, 25, 30, 60" which were used as a sign of distance. In addition, the other information used was "walk, lift truck". This corresponds to the following Figure 7:

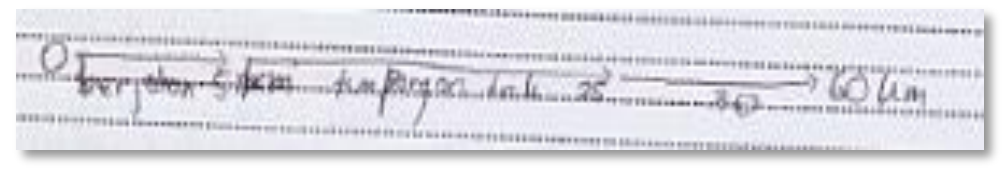

Figure 7 . The scheme drawing created by the subject to devising a plan

\section{Carrying Out the Plan Stage}

At carrying out the plan stage, the subject used a scheme drawing that was created to assist him in performing in solving the problem. Based on the scheme which was equipped with distance information (0 kilometers, 5 kilometers, 25 kilometers, 30 kilometers, 60 kilometers), the subject had been able to determine the distance by using a lift truck as far as 25 kilometers. This result was obtained the subject by understanding that the distance traveled on foot plus a travel with a truck ride still had half of all travel distance. This meant that the walking distance plus the distance 
with the truck ride was half distance of the travel route. So the subject could determine that the distance traveled with a truck ride that was 25 kilometers. The subject's activity in implementing stage is shown in the following Figure 8:

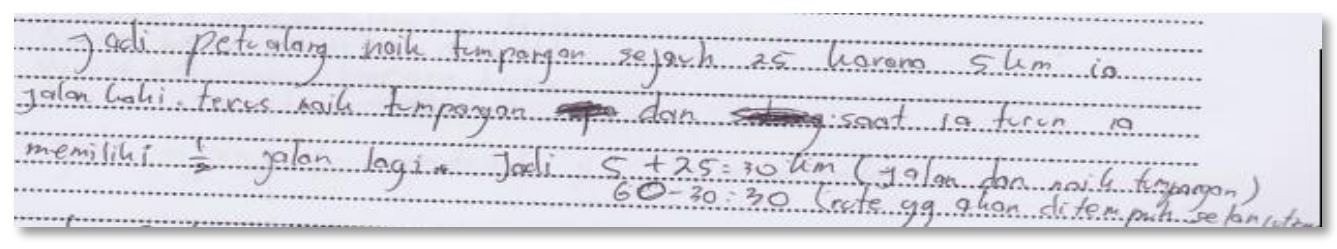

Figure 8. Counting activity

Description of figure 8:

So the adventurer takes a ride as far as 25 kilometers. Because he walks for 5 kilometers, then has a truck ride and when he is off he still has $1 / 2$ way more.

So, $5+25=30$ kilometers (Walk and has truck ride)

$60-30=30$ (The route to go next)

\section{Looking Back Stage}

The activities that the subject did at looking back stage were re-reading and checking the result of his work. Then the subject made the conclusion of his answer by writing the following sentence (Fig. 9):

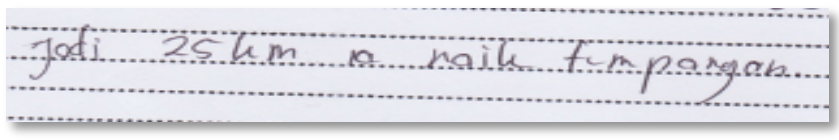

Figure 9. Conclusion of the subject in answering the problem question

Description of Figure 9:

So, he took a ride for 25 kilometers

The pure schematic representation process structure by S2 as a whole is presented in the following Figure 10: 


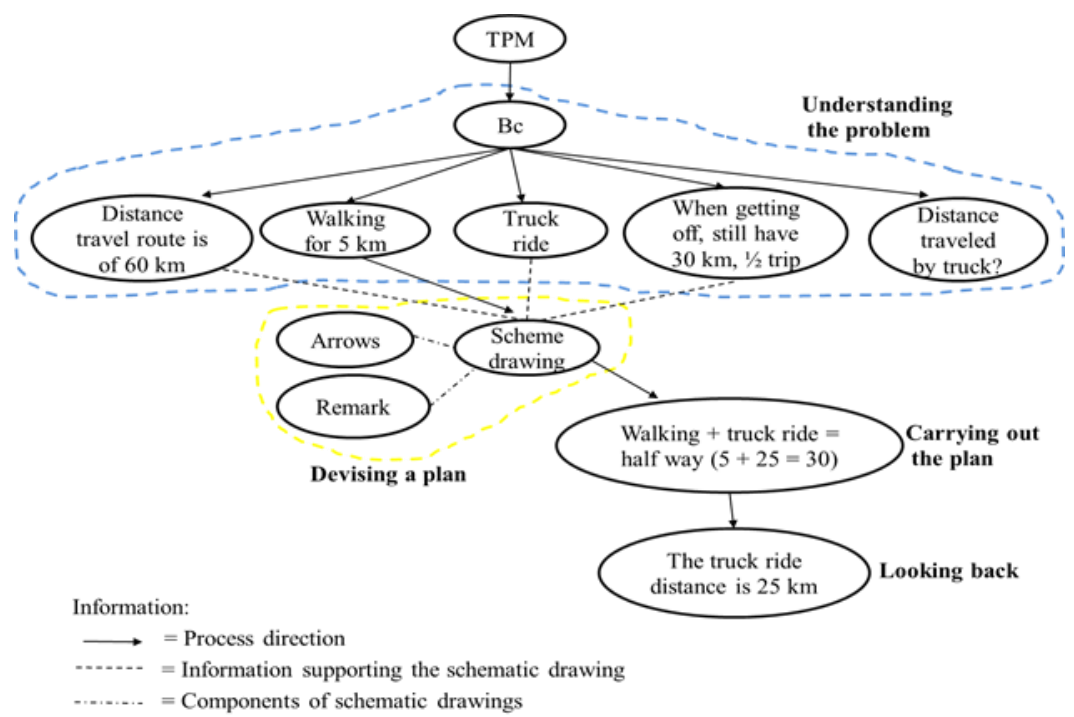

Description of Figure 10 in Table 2:

Table 2. Terms of Pure Schematic Representation Code of S2

\begin{tabular}{ll}
\hline \multicolumn{1}{c}{ Term } & \multicolumn{1}{c}{ Code } \\
\hline Problem solving task & TPM \\
\hline Reading problem Activity & Bc \\
\hline Distance of travel route to be reached IS 60 & Distance travel route is of 60 \\
kilometers & $\mathrm{km}$ \\
\hline The distance traveled by the adventurer by & Walking for $5 \mathrm{~km}$ \\
walking is as far as 5 kilometers & \\
\hline Adventurer gets a ride on a truck & Truck ride \\
\hline After getting off the truck, the adventurer still & When getting off, still have 30 \\
has half of his route & km, 1/2 trip \\
\hline The question of the problem is how much & Distance traveled by truck? \\
distance will be taken by the truck & \\
\hline The subject makes a scheme drawing & Scheme drawing \\
\hline The information in problem & Remark \\
\hline Scheme drawing as arrows & Arrows \\
\hline
\end{tabular}




\begin{tabular}{ll}
\hline Counting activity & Walking + truck ride $=$ half \\
& way $(5+25=30)$ \\
\hline Looking back activity & The truck ride distance is 25 \\
& $\mathrm{~km}$
\end{tabular}

\section{B. Description of Mixed Schematic Representation Process}

\section{Subject 3 (S3)}

\section{Understanding the Problem Stage}

In the process of understanding the problem, the activity undertaken by the subject was reading the given TPM. Then the subject created a scheme drawing to help him in understanding the problem. The scheme drawing created by the subject was an illustration of a street with some other information. The description used by the subject to complete the scheme drawing included: 60 kilometers travel route distance, 5 kilometers walk distance, a sign that the adventurer gets a ride on a truck, and a sign that the adventurer gets off from the vehicle / truck. Scheme drawing created by the subject used to understand the problem as follows (Fig. 11):

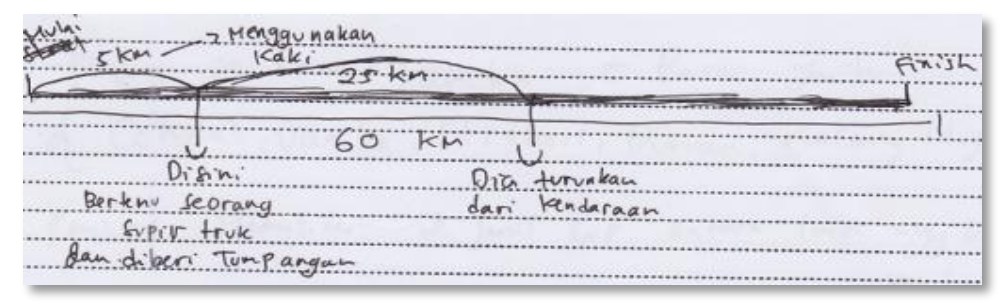

Figure 11. Scheme drawing to understand the problem

\section{Devising a Plan Stage}

At devising a plan stage, the subject's activity was writing descriptions based on the scheme drawing that had been made in understanding the problem. In preparing a plan, the keyword used by the subject was "after getting off the truck, an adventurer still has half of the distance that will be pursued. " This was interpreted by the subject that the distance that had been taken was 30 kilometers. Then the subject can prepare a plan to solve the problem with the following strategy: 
Distance that has been traveled - Distance that is traveled by walking $=$ Distance traveled by truck.

This activity is also shown in the subject's worksheet as follows (Fig. 12):

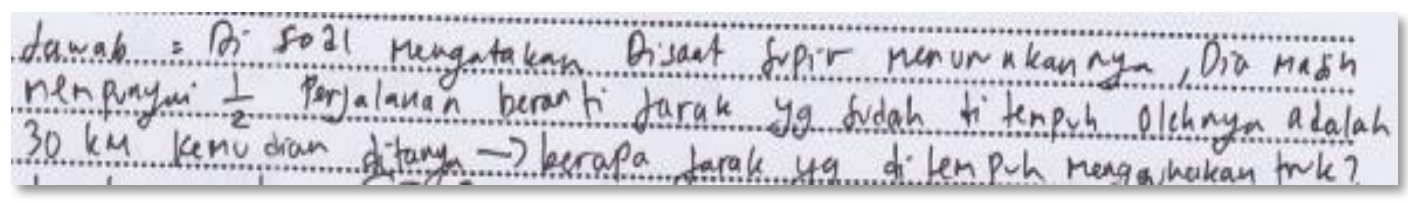

Figure 12. Activity of devising a plan

Description of Figure 12:

Answer: in the problem, it is said when the driver makes the adventurer get off, he still has $1 / 2$ trip. It means the distance that has been taken by him is 30 kilometers. Then asked how long is the distance traveled by truck?

\section{Carrying Out the Plan Stage}

At carrying out the plan stage, the activity undertaken by the subject was doing the calculation in accordance with the strategy that had been made at preparing the plan stage. Counting done by the subject was subtracting the distance that had been taken by the distance that had been taken on foot. The subject's activity in implementing the plan stage is shown in the following Figure 13:

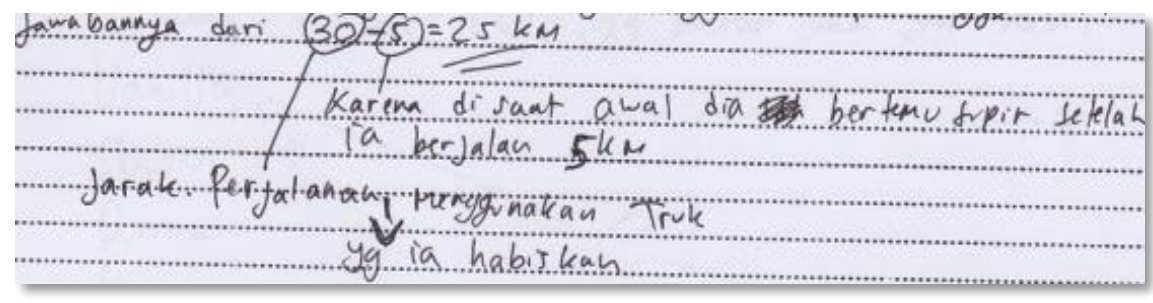

Figure 13. Calculation Activity

Description of Figure 13:

$$
\begin{aligned}
& \text { The answer is from } 30-5 \begin{aligned}
= & 25 \text { kilometers } \\
5 & =\text { Because at the beginning he met the driver after he } \\
& \text { walks } 5 \text { kilometers. }
\end{aligned} \\
& 30=\text { Distance that he spends using trucks. }
\end{aligned}
$$




\section{Looking Back Stage}

At the looking back stage, the activity done by the subject was checking the result of his work by re-reading. Then the subject made the conclusion of his answer by writing the following sentence (Fig. 14):

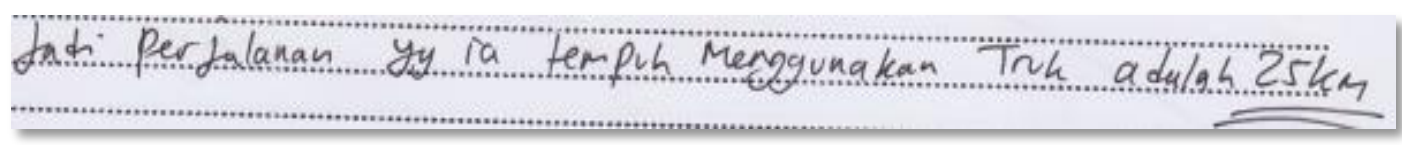

Figure 14. Conclusion of the subject in answering the problem question

Description of Figure 14:

So, the trip that he takes using a truck is 25

The mixed schematic representation process structure of S3 is globally presented in the following Figure 15:

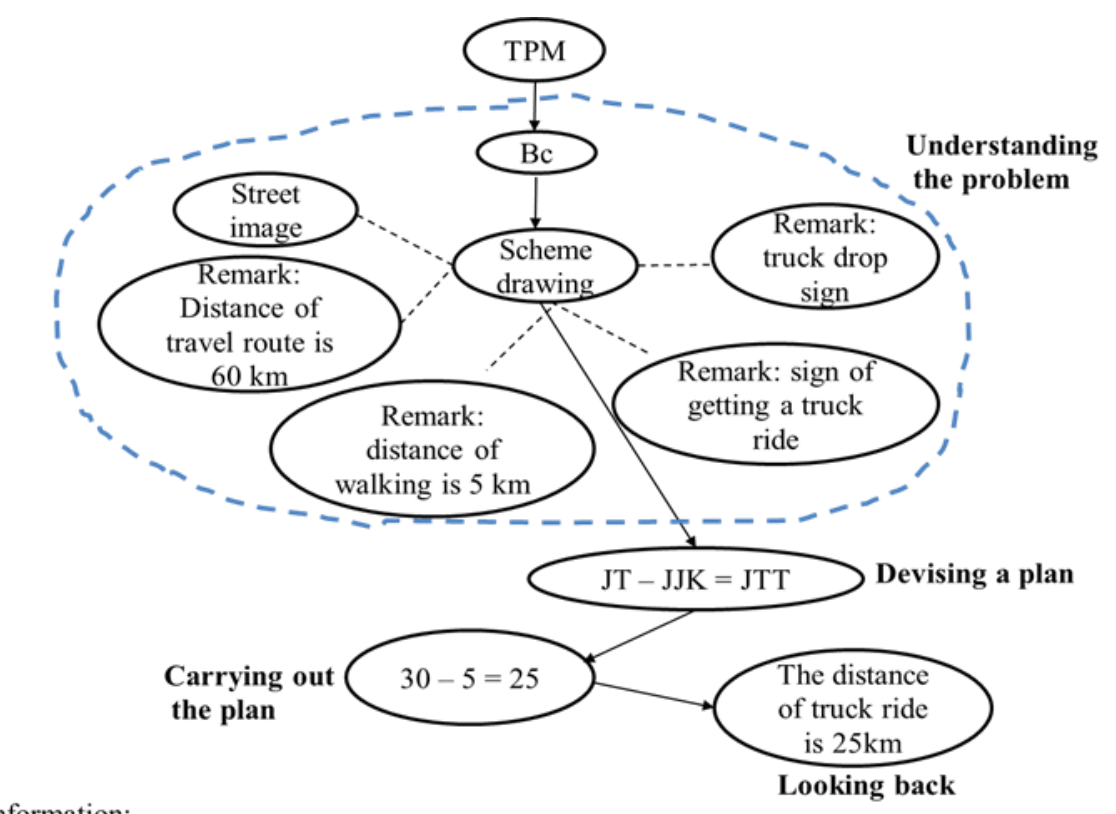

Information:

$\longrightarrow=$ Process direction

- Information supporting the schematic drawing

Figure 15. Mixed Schematic Representation Process Structure of S3

Description of Figure 15 in Table 3: 
Table 3. Terms of Mixed Schematic Representation Code of S3

\begin{tabular}{ll}
\hline \multicolumn{1}{c}{ Term } & \multicolumn{1}{c}{ Code } \\
\hline Problem solving task & Bc \\
\hline Reading problem activity & Scheme drawing \\
\hline Drawing scheme activity & Street image \\
\hline Drawing a line to illustrate a path & Remark: Distance of travel \\
\hline Distance of travel route to be reached is 60 kilometers & route is 60 km \\
& Remark: distance of walking \\
\hline The distance traveled by the adventurer by walking is & is 5 km \\
5 kilometers & Remark: sign of getting a \\
\hline Adventurers get a ride on a truck & truck ride \\
& Remark: truck drop sign \\
\hline The adventurer gets off the truck & JT - JJK = JTT \\
\hline Calculation activity (travelled distance subtracted by & \\
distance of walking so as to obtain distance with truck & \\
ride) & The distance of truck ride is \\
\hline Counting activity & \\
\hline Looking back activity & \\
\hline
\end{tabular}

\section{Subject 4}

\section{Understanding the Problem Stage}

At understanding the problem stage, the subject began by reading the given TPM. Then the subject made a scheme drawing to understand the problem better. The scheme drawing created by the subject was a line that illustrated a path with some other description images. The other images created by the subject in creating a scheme drawing were pictures of cars and people. The image of person made is to represent an adventurer. While the information used by the subject to complete the scheme drawing included: distance of travel route was 60 kilometers, distance traveled by walking was 5 kilometers, a sign where the adventurer got a ride on a 
truck, and a sign where the adventurer got off the truck. The scheme drawing created by the subject used to understand the problem is as follows (Fig. 16):

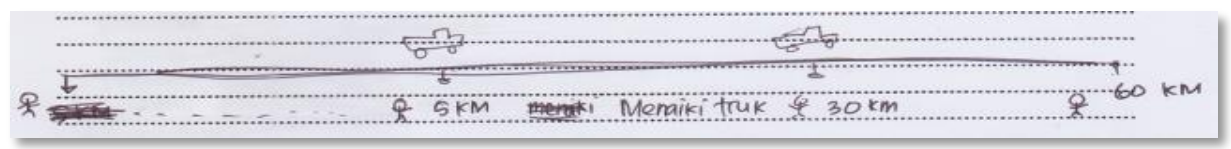

Figure 16. The scheme drawing created by the subject to understand the problem

\section{Devising a Plan Stage}

At devising a plan stage, the activity done by the subject was to make a strategy to solve the problem by dividing the route into two parts. It was based on the information contained in the problem that after getting off the truck, an adventurer still had half of his route. After being known the value of half-distance route of travel, then subtracted by the distance that had been traveled on foot.

\section{Carrying Out the Plan Stage}

At carrying out the plan stage, the activity undertaken by the subject was doing the calculation in accordance with the strategy that had been made at preparing the plan stage. Calculation done by the subject was to divide the route of the trip into two parts, then after the value of half distance of trip was known, then subtracted by the distance traveled on foot. The subject activity in implementing the Plan Stage is shown in the following Figure 17:

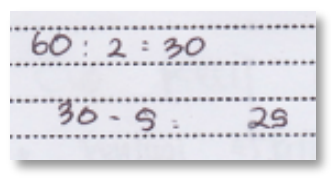

Figure 17. Calculation Activity

\section{Looking Back Stage}

At looking back stage, the activity done by the subject was checking and re-reading the result of his work.

The mixed schematic representation process structure of S4 is globally presented in the following Figure 18: 
Information:

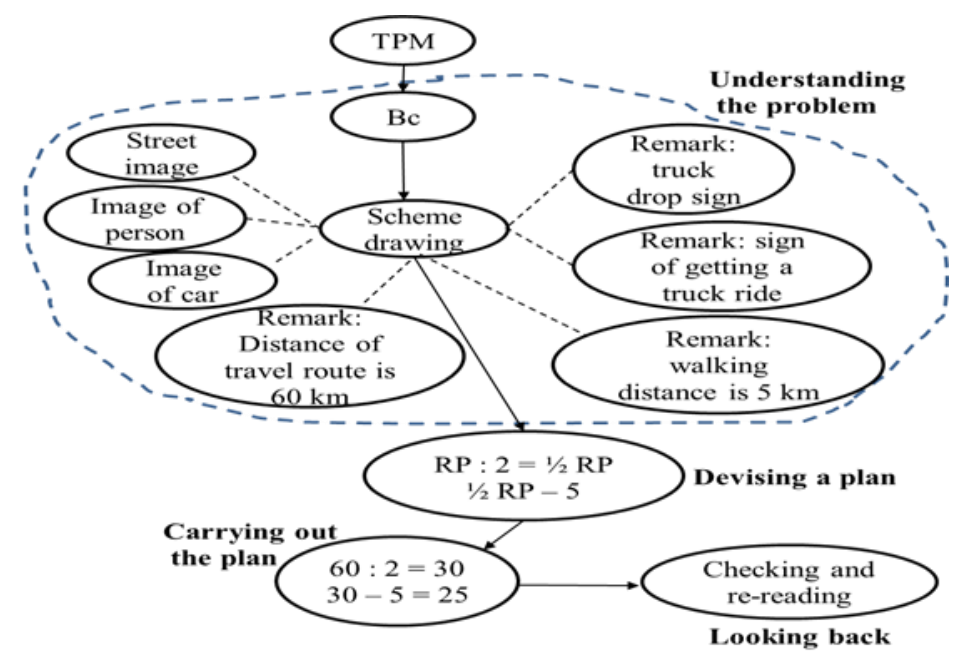

$\longrightarrow=$ Process direction

$\longrightarrow-\longrightarrow_{-}=$Process direction
$=$Information supporting the schematic drawing

Figure 18. Mixed Schematic Representation Process Structure of S4

Description of Figure 18 in Table 4:

Table 4. Terms of Mixed Schematic Representation Code of S4

\begin{tabular}{ll}
\hline \multicolumn{1}{c}{ Term } & \multicolumn{1}{c}{ Code } \\
\hline Problem solving task & TPM \\
\hline Reading problem activity & Scheme drawing \\
\hline Creating a scheme drawing activity & Street image \\
\hline Drawing a line to illustrate a path & Image of person \\
\hline The subject creates a picture of a person & \\
illustrates the adventurer & Image of car \\
\hline The subject makes a car image to illustrate the truck & \\
that gives a ride & Remark: Distance of \\
\hline Distance of travel route to be reached is 60 kilometers & travel route is 60 km \\
\hline The distance traveled by the adventurer by walking is & Remark: \\
5 kilometers & distance is 5 km \\
\hline The adventurer gets a ride on a truck & Remark: sign of getting \\
& a truck ride \\
\hline
\end{tabular}


The adventurer gets off the truck

Remark: truck drop

sign

\begin{tabular}{ll}
\hline Activity calculation (distance of travel route is divided & $\mathrm{RP}: 2=30$ \\
by two, it is $1 / 2$ of travel route distance), then half of & $1 / 2 \mathrm{RP}-5=25$ \\
travel route distance is subtracted by the distance & \\
traveled by walking & Checking and re- \\
\hline Looking back Activity & reading
\end{tabular}

\section{DISCUSSION}

\section{Pure Schematic Representation Process}

Based on the exposure of the research data, the pure schematic representation process began by understanding the problem indicated by writing down some information obtained by the problem. The information written by the subject indicates that the subject had understood the problem. Understanding the problem is the most important step in solving a mathematical problem (Polya, 1957).

Based on the information that was known the subject made a scheme drawing in the form of lines equipped with distance description. By using a scheme drawing, the subject succeeded in preparing a plan to solve the problem. This result was in accordance with Polya's (1957) opinion that using visualization of a problem could be a success factor in problem solving. In addition, Bikić, et al, (2016) states that in order to solve the problem students must find the right strategy in order to achieve its goals. While Newell \& Simon (1972) mention with representation students can use it as a means to combine all the information contained in the problem.

Furthermore, based on a plan prepared to solve the problem, the subject performed a series of calculations. Calculations made by the subject included subtracting the length of the trip route subtracted by half of the travel distance subtracted by trip on foot. So that the travel distance by truck was obtained. By using the scheme created in preparing the plan, the subject succeeded in doing the calculation. After obtaining the result of the calculation, the subject checked again by reading and reviewing the result of his work and writing down the answer of the 
problem question. The result indicated that the schematic representation could provide important assistance to students in solving problems (Fagnant \& Vlassis, 2013).

\section{Mixed Schematic Representation Process}

Mixed schematic representation process began by understanding the problem shown by creating a scheme drawing. The scheme drawing created by the student was in the form of an illustration of the object contained in the problem, in the form of a road equipped with some other descriptions. The other descriptions used by the subject to complete the scheme drawing included: the distance of the trip route, the distance traveled by walking, the sign where the adventurer gets a ride on the truck, and the sign where the adventurer gets off the truck. At this stage, by making scheme drawing the subject succeeded in understanding the problem well. This was in accordance with the opinion of Van Garderen \& Montague (2003) that a student who is successful in solving a problem generally built representations to facilitate in understanding the problem. The process of understanding the problems with by making schemes was one strategy that could be used in solving word problems because the scheme could be used to dismantle the structure of the problem, simplify complex problems, and make abstract concepts become more concrete (Diezmann \& English, 2001; Novick, Hurley, \& Francis, 1999). In addition Presmeg (1992) argues that the use of concrete images can help focus the minds of students in detailing the main elements of the problem to represent the problem situation.

At the stage of preparing the plan, the subject activity was in the form of strategy to solve the problem based on scheme drawing that had been made. Using scheme drawing could facilitate students in exploring problems (Stylianou \& Silver, 2004) so the subject could get the keywords that the subject used in preparing the plan. The keywords used by the subject were "after getting off from the truck, an adventurer still has half of the distance that will be pursued." It was interpreted by the subject that the distance that had been taken was 30 kilometers. The keywords used by the subject in this plan were very precise. 
After determining the strategy for solving the problem, the subject performed a series of calculations based on the strategies prepared during the planning stage. The calculation done by the subject was dividing the route of the trip into two parts. After knowing the value of half distance of the trip route, it was followed by subtracting the distance traveled on foot. After obtaining the result of the calculation, the subject checked again by reading and reviewing the result of his work and writing down the answer to the problem question. By using a representation the subject could monitor or review the problem solving process that had been done (Izsa'k, 2003).

\section{CONCLUSION}

The result of this study indicates that pure schematic representation and mixed schematic representation strongly support students in solving word problems. The process of pure schematic representation starts from; 1) reading and understanding the problem, writing the information that is known and asked from the problem, 2) making the scheme drawing equipped with the main information of the problem, and obtaining a strategy to solve the problem; 3) performing a series of calculations based on the strategy prepared, 4) reading and re-checking the result of work and writing a conclusion based on the problem question.

The process of mixed schematic representation starts from; 1) reading and understanding the problem, creating a scheme drawing with descriptions and drawings appropriate to the situation in the problem; 2) preparing a plan to solve the problem based on the scheme drawing created; 3) undertaking a series of settlements based on the prepared strategy; 4) Reading and re-checking the result of work and writing a conclusion based on the problem question.

\section{REFERENCE}

Anwar, R., B., Yuwono, I., As'ari, A., R., Sisworo, \& Rahmawati, D. (2017). Identifikasi Representasi Skematis Dalam Menyelesaikan Masalah Matematika. Proceedings of National Seminar on Mathematics Education 2017, ISBN: 978-602-61923-0-1 (pp. 417 -425). Malang: Indonesia.

Bikić, N., Maričić, S., M., \& Pikula, M. (2016). The effects of differentiation of content in problem-solving in learning geometry in secondary school. Eurasia 
Journal of Mathematics, Science \& Technology Education, 2016, 12(11), 2783-2795 doi: 10.12973/eurasia.2016.02304a

Boonen, A. J. H., Van der Schoot, M., Van Wesel, F., De Vries, M. H., \& Jolles, J. (2013). What Underlies Successful Word Problem Solving? A Path Analysis in Sixth Grade Students. Contemporary Educational Psychology, 38, 271279.

Boonen, J. H. A., Wesel, F. V, Jolles, J., \& Schoot, M.V. D. (2014). The Role of Visual Representation Type, Spatial Ability, and Reading Comprehension in Word Problem Solving: An Item-Level Analysis in Elementary School Children. International Journal of Educational Research.

Diezmann, C. M., \& English, L. D. (2001). Promoting the Use of Diagrams as Tools for Thinking. In A. A. Cuoco \& F. R. Curcio (Eds.), The Roles of Representation in School Mathematics: 2001 yearbook (pp. 77-89). Reston, VA: National Council of Teachers of Mathematics.

Fagnant, A., \& Vlassis, J. (2013). Schematic Representations in Arithmetical Problem Solving: Analysis of Their Impact on Grade 4 Students. Educational Studies in Mathematics 84:149-168 DOI 10.1007/s10649-013-9476-4.

Faruq, A., Yuwono, I., \& Chandra, T., D. (2016). Proses Representasi Skematik pada Penyelesaian Soal Cerita Matematika. Proceedings of National Seminar on Mathematics Education, ISBN 978-602-1150-19-1 (pp. 839 - 848). Malang: Indonesia.

Hegarty, M. \& Kozhevnikov, M. (1999). Types of Visual-Spatial Representations and Mathematical Problem Solving. Journal of Educational Psychology 1999, Vol. 91, No. 4,684-689.

Izsa'k, A. (2003). "We Want a Statement That is Always True': Criteria for Good Algebraic Representations and the Development of Modeling Knowledge. Journal for Research in Mathematics Education, 34(3), 191-227.

Jupri, A., \& Drijvers, P. (2016). Student Difficulties in Mathematizing Word Problems in Algebra. Eurasia Journal of Mathematics, Science \& Technology Education, 2016, 12(9), 2481-2502 doi: 10.12973/eurasia.2016.1299a.

Muttaqien, A. (2016). Representasi Matematis Pada Pemecahan Word Problem Perbandingan Inkonsisten. Jurnal Review Pembelajaran Matematika, (JRPM, 2016, 1(2), 99-116)

Newell, A., \& Simon, H. (1972). Human Problem Solving. Englewood Cliffs, NJ: Prentice Hall.

Novick, L. R., Hurley, S. M., \& Francis, M. (1999). Evidence for Abstract, Schematic Knowledge of Three Spatial Diagram Representations. Memory \& Cognition, 27(2), 288-308.

Pape, S. J. (2003). Compare Word Problems: Consistency Hypothesis Revisited. Contemporary Educational Psychology, 28, 396-421. http://dx.doi.org/10.1016/ S0361-476X(02)00046-2

Polya, G. (1957). How to solve it: A New Aspect of Mathematical Method (2nd ed.). Garden City, NY: Doubleday \& Company, Inc.

Polya, G. 1973. How To Solve It: A New Aspect of Mathematical Method. Second Edition. New Jersey: Pricenton University Press. 
Stylianou, D. A., \& Silver, E. A. (2004). The Role of Visual Representations in Advanced Mathematical Problem Solving: An Examination of Expert-Novice Similarities and Differences. Mathematical Thinking and Learning, 6(4), 353-387.

VandenBos, G., R. (2015). American Psychological Association (APA) Dictionary of Psychology- Second Edition. Washington, DC: Maple Press.

Van Garderen, D., \& Montague, M. (2003). Visual-Spatial Representation, Mathematical Problem Solving and Students of Varying Abilities. Learning Disabilities Research and Practice, 18(4), 246-254.

Vula, E., Avdyli, R., Berisha, V., Saqipi, B., \& Elezi, S. (2017). The impact of metacognitive strategies and self-regulating processes of solving math word problems. International Electronic Journal of Elementary Education, DOI: 10.26822/iejee.2017131886.

Zahner, D., \& Corter. J., E. (2010). The Process of Probability Problem Solving: Use of External Visual Representations. Mathematical Thinking and Learning, 12: 177-204, 2010. ISSN: 1098-6065 print / 1532-7833 online. DOI: 10.1080/10986061003654240. 